\title{
Recent advances in understanding multiple sclerosis [version
}

\section{1; peer review: 2 approved]}

\author{
Peter K. Stys (D), Shigeki Tsutsui \\ Department of Clinical Neurosciences, Hotchkiss Brain Institute, Medicine University of Calgary, Calgary, Alberta, Canada
}

V1 First published: 13 Dec 2019, 8(F1000 Faculty Rev):2100

https://doi.org/10.12688/f1000research.20906.1

Latest published: 13 Dec 2019, 8(F1000 Faculty Rev):2100

https://doi.org/10.12688/f1000research.20906.1

\section{Abstract}

Emerging data point to important contributions of both autoimmune inflammation and progressive degeneration in the pathophysiology of multiple sclerosis (MS). Unfortunately, after decades of intensive investigation, the fundamental cause remains unknown. A large body of research on the immunobiology of MS has resulted in a variety of anti-inflammatory therapies that are highly effective at reducing brain inflammation and clinical/radiological relapses. However, despite potent suppression of inflammation, benefit in the more important and disabling progressive phase is extremely limited; thus, progressive MS has emerged as the greatest challenge for the MS research and clinical communities. Data obtained over the years point to a complex interplay between environment (e.g., the near-absolute requirement of Epstein-Barr virus exposure), immunogenetics (strong associations with a large number of immune genes), and an ever more convincing role of an underlying degenerative process resulting in demyelination (in both white and grey matter regions), axonal and neuro-synaptic injury, and a persistent innate inflammatory response with a seemingly diminishing role of $\mathrm{T}$ cell-mediated autoimmunity as the disease progresses. In our opinion, these observations together point toward a primary degenerative process, one whose cause remains unknown but one that entrains a nearly ubiquitous secondary autoimmune response, as a likely sequence of events underpinning this disease. Here, we briefly review what is known about the potential pathophysiological mechanisms, focus on progressive MS, and discuss the two main hypotheses of MS pathogenesis that are the topic of vigorous debate in the field: whether primary autoimmunity or degeneration lies at the foundation. Unravelling this controversy will be critically important for developing effective new therapies for the most disabling later phases of this disease.

Keywords

multiple sclerosis

\section{Open Peer Review}

Approval Status

1

2

version 1

13 Dec 2019

Faculty Reviews are review articles written by the prestigious Members of Faculty Opinions. The articles are commissioned and peer reviewed before publication to ensure that the final, published version is comprehensive and accessible. The reviewers who approved the final version are listed with their names and affiliations.

1. Ranjan Dutta, Cleveland Clinic, Cleveland, USA

2. Frauke Zipp, University Medical Center of the Johannes Gutenberg University Mainz, Mainz, Germany

Any comments on the article can be found at the end of the article. 
Corresponding author: Peter K. Stys (pstys@ucalgary.ca)

Author roles: Stys PK: Conceptualization, Writing - Original Draft Preparation, Writing - Review \& Editing; Tsutsui S: Conceptualization, Writing - Original Draft Preparation, Writing - Review \& Editing

Competing interests: No competing interests were disclosed.

Grant information: This work was supported by the Alberta Prion Research Institute, Alberta Innovates Health Solutions, MS Society of Canada and Canada Research Chairs.

The funders had no role in study design, data collection and analysis, decision to publish, or preparation of the manuscript.

Copyright: ( 2019 Stys PK and Tsutsui S. This is an open access article distributed under the terms of the Creative Commons Attribution License, which permits unrestricted use, distribution, and reproduction in any medium, provided the original work is properly cited.

How to cite this article: Stys PK and Tsutsui S. Recent advances in understanding multiple sclerosis [version 1; peer review: 2 approved] F1000Research 2019, 8(F1000 Faculty Rev):2100 https://doi.org/10.12688/f1000research.20906.1

First published: 13 Dec 2019, 8(F1000 Faculty Rev):2100 https://doi.org/10.12688/f1000research.20906.1 


\section{Introduction}

Multiple sclerosis (MS) is one of the most common causes of neurological disability in young adults. The etiology of MS has been intensively investigated for over a century, and although much has been discovered about the immunobiology, genetics, and epidemiology of this disease, the fundamental cause remains a mystery. MS is distinguishable from most other chronic neurological disorders by its unique fluctuating course; the majority of patients with MS present with early relapsing and remitting episodes of neurological and radiological worsening followed by varying degrees of recovery (relapsing-remitting MS, or RRMS) ${ }^{1}$. In most patients, this initial relapsing remitting phase is followed years later by a more chronic progressive phase (secondary progressive MS, or SPMS), whereas a minority $(\approx 15 \%)$ of patients begin with a progressive course from onset (primary progressive MS, or PPMS) for unknown reasons.

Traditionally, the etiology of MS was based on an "outside-in" autoimmune hypothesis whereby dysregulated auto-reactive $\mathrm{T}$ cells in the periphery cross into the central nervous system (CNS) parenchyma and, together with macrophages and B cells, proceed to attack various CNS elements, where myelin is a prominent target. These inflammatory events, resulting in a relapsing-remitting clinical course, likely contribute independently to accumulating CNS injury. As a result, most work in the field has been directed at the autoimmune inflammatory nature of the disease, resulting in over a dozen US Food and Drug Administration/European Medicines Agency-approved treatments to date ${ }^{2}$. This traditional model is being challenged by a competing theory proposing that the initial malfunction occurs within the CNS, as suspected for other neurodegenerative disorders such as Alzheimer's and Parkinson's diseases ${ }^{3-7}$. This alternative "inside-out" hypothesis argues that MS is a primary degenerative disease and is accompanied by varying degrees of inflammation, leading to the release of antigenic cell components such as myelin oligodendrocyte glycoprotein, myelin basic protein, and proteolipid protein $^{8,9}$. This chronic shedding of auto-antigens secondarily promotes an autoimmune inflammatory response in the predisposed host, in turn driving additional degeneration in a vicious cycle. The extent of inflammatory activity, which varies by patient and over time within the same individual, determines the spectrum of MS phenotypes. Importantly, the "inside-out" hypothesis maintains that primary degeneration is present from the start (probably years before the first overt clinical symptoms) and continues throughout the entire course of the disease. Given that CNS inflammation in MS can be well controlled with modern therapies, the current challenge is progressive disease, during which most irreversible disability occurs ${ }^{10,11}$. At present, we neither understand the mechanisms driving this phase of MS nor have very effective treatment options for patients in whom degeneration predominates in the absence of overt inflammation. The goal of this commentary is to touch on some recent findings and discuss recent advances regarding progressive MS pathogenesis.

\section{MS stages and clinical progression}

Much effort has been expended in an attempt to accurately classify the various stages of MS. Clinical relapses at a younger age, coupled with radiological evidence of CNS inflammation, provide good support for the earlier relapsing-remitting phase of MS. This may be important from a practical point of view to guide clinical therapeutic decisions given the many options for effective anti-inflammatory agents that are currently available. But with time, identifying the transition from relapsing to secondary progressive disease often becomes problematic; absence of clinical relapses does not imply absence of inflammatory activity on magnetic resonance imaging, and absence of inflammatory radiological lesions does not imply lack of inflammation at the tissue level. Indeed, it has been proposed that MS is a condition in which disability progression is driven in two stages, and early relapsing inflammatory activity has little influence on the second, later stage of progressive deterioration ${ }^{12}$. Therefore, identifying the transition to secondary progression has important practical implications because it appears that our current anti-inflammatory drugs offer little benefit in the absence of ongoing inflammatory activity; continuing treatment entails expense and potential risk from potent immunosuppressants with potentially little benefit in return. This is not to say that inflammation disappears at later stages. Indeed, recent studies show that substantial inflammatory lesion activity persists well into the progressive phase and, perhaps counterintuitively, that SPMS and PPMS samples exhibit a higher lesion load compared with relapsing subjects ${ }^{13}$. Moreover, there are few differences in lesion morphology or immunopathology in SPMS versus PPMS brain $^{14}$, even though decades of recurrent inflammatory attack preceded the former. Instead, the quality of ongoing inflammation seems to shift in favor of activated macrophages/microglia. The MS brain in progressive stages shows ongoing cortical demyelination and slowly expanding demyelinating lesions in the white matter with such lesions recently shown to be important predictors of future disability ${ }^{15}$. Interestingly, there is scant lymphocytic activity (B cells are a peculiar exception; see below); instead, microglial activation is seen at the borders of expanding lesions ${ }^{16}$. This suggests that adaptive autoimmunity plays a lesser role at this stage and that innate responses predominate. A key question is whether innate immune cells are somehow dysregulated and become primary drivers of degeneration, or simply react as they are expected to, against an unidentified primary injury that itself is the underlying cause of tissue destruction. Taken together, recent data seem to support the idea that all types of MS might be variations of a similar underlying pathophysiological theme and that degeneration and concomitant inflammation begin early and proceed inexorably, regardless of whether relapse activity is a prominent feature ${ }^{17}$. If so, why some patients assume a more relapsing inflammatory pattern at first whereas others begin later with a progressive course is unclear. Here, the genetic background and environment likely play major roles in programming the various clinical phenotypes without the need to invoke fundamentally different disease mechanisms.

\section{The genetics of MS}

In MS, as in most other neurodegenerative diseases, genetic influences play an important role as well. However, unlike in a number of other neurodegenerative disorders, where specific mutations have been identified as causes for at least a subset of these, such mutations have yet to be identified in $\mathrm{MS}^{18-20}$. Instead, a large number of susceptibility loci, the vast majority of which are related to immune function, have been found through 
genome-wide association studies (GWASs) ${ }^{20-27}$. Together, these studies unequivocally confirm the importance of immune-related genes, and genetic maps from a very recent GWAS further implicate both the adaptive and innate immune systems ${ }^{28}$. Examples include the human leukocyte antigen (HLA) class II (DP, DQ, and DR) haplotypes which demonstrate an association with $\mathrm{MS}^{29}$, although contradictory results were shown in various studies among different races $^{30,31}$. The HLA-DRB1*15:01 allele is one of the most intensively studied ${ }^{31,32}$, exhibiting a consistent association with a lower age of onset, greater white matter lesion volume, and faster brain atrophy in RRMS ${ }^{33}$. In addition, a recent report suggested that the high-risk HLA genotype (two predisposing haplotypes) associates with significant reduction in whole brain and grey matter volumes compared with medium- or low-risk genotypes (one or no predisposing haplotypes $)^{34}$. Many loci outside the major histocompatibility complex (MHC) have also been correlated with MS risk and involve other immune pathways, including B-cell activation, cytokine release, and activation of immune cells both in the periphery and within the $\mathrm{CNS}^{27}$. This study identified additional novel candidates associating with regulators of $\mathrm{CD}^{+} \mathrm{Th} 1$ and Th17 induction and apoptosis ${ }^{27}$. Genes involved in neurodegeneration, such as mitochondrial genes $C R Y A B, C B 1$ and Prnp, have been studied, but associations with PPMS risk seem to involve mainly variants of immune-related genes, similar to what was found with relapse-onset $\mathrm{MS}^{32}$. However, none of these has a strong association with progressive MS, suggesting that these immune-related factors are unlikely to be causative but instead might determine the intensity of autoimmune reactivity to a degenerating brain. Genetic studies on patients with PPMS are less comprehensive because of the much lower incidence of this MS phenotype. However, despite the striking difference in clinical phenotypes between relapse-onset MS and PPMS, clear genetic differences have not emerged ${ }^{32}$. Interestingly, however, MS patients exhibiting a higher degree of neurodegeneration had variants in genes related to glutamate signaling ${ }^{35,36}$, supporting the concept of a neurodegenerative underlay driven at least in part by "chronic excitotoxicity". Moreover, such chronic excitotoxicity is likely further exacerbated by glutamate released by immune cells $^{37}$. Finally, we recently showed that primary myelin damage is a strong trigger for a secondary immune reaction driven in large part by biochemically altered myelin proteins ${ }^{38}$; it is quite likely that chronic excitotoxicity, originating from both the as-yet-unknown underlying degenerative process(es) and glutamate release from infiltrating immune cells, promotes a persistent source of pathological myelin products resulting in a vicious cycle of degeneration-inflammation-more degeneration ${ }^{39}$. Taken together, data so far unequivocally support the contribution of multiple immune-related genetic loci to relapsing-remitting inflammatory MS, but a direct causal relationship remains elusive. A thought-provoking parallel can be drawn with genetic studies of human susceptibility to tuberculosis (TB), for instance. The genetics of TB, like those of MS, are complex, but there are interesting similarities, including the greater susceptibility of mono- versus dizygotic twins and association with HLA class I and $\mathrm{II}^{40}$. Because we now know the underlying cause of TB, these genetic studies instead provide important insight into host susceptibility and response to an external pathogen. One could similarly argue that studies of MS genetics also provide information on host susceptibility and response to some causative factor that nonetheless remains unknown. By extension, elucidating multiple immune-related genetic loci associated with MS may not bring us any closer to identifying the root cause any more than such studies would have helped in isolating the TB bacillus.

\section{Environmental factors}

In addition to immunogenetics, MS risk is strongly associated with environmental factors, in particular infection with Epstein-Barr virus (EBV), sun exposure/vitamin D deficiency, and smoking $^{41,42}$. Past EBV exposure as evidenced by seropositivity to the virus is virtually a prerequisite for developing $\mathrm{MS}^{43,44}$. However, given the very high global prevalence of EBV exposure, clearly the converse is not true; that is, only a small minority of exposed individuals will develop MS, indicating that EBV may be necessary but not sufficient to trigger the disease. Epidemiological evidence supporting the important role of this virus includes observations that patients with a history of symptomatic EBV infection carry a higher risk of developing $\mathrm{MS}^{45}$, and the risk of MS dramatically increases in seronegative individuals after seroconversion ${ }^{46}$. These strong associations lead to the hypothesis that B-lymphotropic EBV infection of CNS-infiltrating B cells may somehow drive MS pathology ${ }^{47}$, although such a direct causative role of EBV remains controversial as some groups report absence of EBV infection in MS brain $^{48,49}$. A possible explanation for this discrepancy is that $\mathrm{EBV}$ is one of many possible triggers of secondary autoimmune response or that EBV alone is not sufficient ${ }^{50}$. Although there is no consensus regarding a direct role of EBV-infected $\mathrm{B}$ cells as a primary cause of MS, increasing evidence, including therapeutic strategies, indicates a potentially important role in MS pathogenesis. For instance, recently, a preliminary clinical trial of autologous EBV-specific T-cell therapy showed clinical improvement in patients with progressive $\mathrm{MS}^{51}$. Although only 10 subjects underwent treatment, this small study provides some of the most direct evidence to date of a potentially central role of EBV-infected B cells in MS. Moreover, the fact that patients in the progressive phase, a phase largely resistant to current therapies, experienced improvement is equally noteworthy. Whether the beneficial effects of $\mathrm{T}$ cell-mediated killing of EBV-infected B cells were due to a reduction of disease-causing immunoglobulin production, or of other toxic soluble factors produced by B cells ${ }^{52}$, remains to be seen.

\section{MS Pathology}

Although an inflammation-mediated demyelination of white matter tracts with partial preservation of axons is a hallmark of MS, recent advances in histopathological/imaging techniques have emphasized the prevalence of cortical demyelination, where lymphocyte or macrophage infiltrates are limited ${ }^{53-57}$. Cortical demyelination and grey matter demyelination in cerebellar cortex, hippocampus, and deep grey matter nuclei are major histological features of progressive $\mathrm{MS}^{58-61}$. Evidence suggesting that grey matter involvement is related to disease activity and more aggressive forms is growing. Recent studies have shown that cortical and deep grey matter lesions in the thalamus, caudate, putamen, and cerebellar cortex during the early stage of disease are independent of white matter pathology $y^{62,63}$. These recent findings strongly support the hypothesis proposed a decade ago that neurodegeneration becomes independent of 
inflammation during progressive $\mathrm{MS}^{4}$ and that MS could be a primary degenerative disease. In support of these findings, inflammatory relapses were recently reported to be associated with transient short-term disability, but long-term worsening was largely independent of relapses ${ }^{17}$. The authors proposed the concept of "silent progression" that is consistent with an underlying degenerative process, which proceeds largely independently of autoimmune inflammation ${ }^{17}$. The age and gender differences between relapse-onset MS (younger age at onset and greater prevalence in women) and PPMS (later age at onset and equal prevalence among the sexes) do not necessarily imply a fundamentally different etiology. Just as with TB susceptibility discussed above, such differences can be readily explained by the known difference in autoimmune predilection which is greater in women ${ }^{64}$; a subject afflicted with the same underlying cytodegeneration, but more prone to react with an inflammatory lesion, would naturally present earlier (inflammatory lesions in eloquent regions of the CNS will result in more obvious clinical disability). As age and accompanying immune senescence progress, MS at later ages would be expected to exhibit less inflammation.

In contrast to RRMS, which has major involvement of peripheral immune cell infiltration in actively demyelinating plaques, progressive MS may involve the development of compartmentalized pathological processes within the resident CNS cells. Microglia are the most abundant resident macrophage-like cells in the CNS and constitute one of the key cell types that could trigger neurotoxic pathways leading to progressive neurodegeneration or, in contrast, could exert important roles in promoting neuroprotection, downregulation of inflammation, and stimulation of repair. Activated microglia exhibit cytoplasmic hypertrophy, retraction of processes, and upregulation of MHC class II molecules and pro-inflammatory cytokines ${ }^{65}$. Microglial activation not only is observed in early active lesions but also accompanies diffuse axonal injury in normal-appearing white and grey matter of progressive MS lesions ${ }^{66}$. In addition, microglial nodules (a clustering of activated microglia) are abundant in the areas adjacent to plaques, particularly in patients with progressive $\mathrm{MS}^{67}$. In an attempt to understand the neuropathological processes occurring in progressive MS, a positron emission tomography (PET) imaging method with radioligands binding to the $18-\mathrm{kDa}$ translocator protein (TSPO) molecule on activated microglia was developed for monitoring these cells in living patients with $\mathrm{MS}^{68}$. This revealed that TSPO binding was significantly increased in the normal-appearing white matter (NAWM) of patients with SPMS $^{69-71}$ but only modestly in the NAWM of RRMS brain ${ }^{70}$. In PPMS, such studies are still limited ${ }^{72}$. Most recently, TSPOPET studies showed significantly increased signals in subcortical grey matter regions, especially in thalamus in SPMS, and this was associated with accelerated brain atrophy ${ }^{73}$. Thus, activated microglia are observed in progressive MS; however, what is not yet known is whether they contribute to ongoing degeneration or reflect a normal reaction to injury and serve a protective role.

\section{Mitochondrial dysfunction in MS}

Mitochondria play a central role in the supply of energy to electrically active axons and neurons. Dysfunction of this organelle likely contributes to "virtual hypoxia" especially relevant for chronically demyelinated axons where an action potential may exact a higher toll on energy supply. This imbalance of supply versus demand could further exacerbate degeneration of vital tracts through energy failure, induction of apoptosis, and enhanced production of reactive oxygen species ${ }^{75}$. Therefore, this topic has been gaining interest as an important mechanism of neuronal death. Oxidative burst in activated microglia produces reactive oxygen and nitrogen species which contribute to mitochondrial dysfunction ${ }^{76}$. Therefore, the activated microgliosis described above could exacerbate axo-glial injury in white matter that does not exhibit overt pathological changes (NAWM). A marker of mitochondrial dysfunction, cerebrospinal fluid (CSF) lactate showed a positive correlation with disease onset, severity, and progression ${ }^{77-79}$, suggesting that this organelle might be under stress from the earliest stages of the disease. A recent study reported that ceramides in CSF from patients with progressive MS induced mitochondrial elongation and reduced respiratory chain complex activity in cultured neurons, providing evidence of a specific factor contributing to mitochondrial injury ${ }^{80}$. This supports previous findings that decreased functional activity of mitochondrial respiratory chain complexes in progressive MS motor cortex neurons may contribute to accumulating neurological disability in patients with $\mathrm{MS}^{81}$. In addition, respiratory chain complex IV-deficient neurons and choroid plexus (CP) epithelial cells are more abundant in MS brain and this respiratory enzyme deficiency is caused by a high level of mitochondrial DNA (mtDNA) deletions $^{82,83}$ (reviewed in 84). Interestingly, no significant change in the extent of respiratory-deficient skeletal muscle fibers was found in patients with progressive MS compared with agematched controls ${ }^{85}$, indicating that such mitochondrial changes are induced within the CNS. The cause of this mitochondrial damage, which likely plays an important role in further compromising the health and function of brain neurons and axons, is not completely understood.

\section{Conclusions}

It is very clear that both degenerative and immune processes are involved in the pathophysiology of MS. Unfortunately for the MS researcher, the closely intertwined relationship between these two processes, continuing throughout all phases of the disease, makes it extremely difficult to definitively resolve the "outside-in" versus "inside-out" controversy. In our opinion, emerging evidence, as summarized in this commentary, is providing increasing support in favor of a primary degenerative etiology. However, as with most other neurodegenerative disorders, the proximal trigger is unknown. Regardless, what is clear is that understanding the mechanisms of chronic progression in MS is currently the major challenge because this is the phase that contributes most to irreversible disability. The lack of insight into mechanisms of progression is largely responsible for the extremely limited treatment options currently available to patients with progressive MS. A shift in thinking about this disease, with greater consideration given to a potential underlying degenerative etiology, will spur new and original research directions that will eventually unravel the mystery and provide more effective therapeutics to mitigate the disabling progressive phase of MS. 
1. F Polman $\mathrm{CH}$, Reingold SC, Banwell B, et al:: Diagnostic criteria for multiple sclerosis: 2010 revisions to the McDonald criteria. Ann Neurol. 2011; 69(2): 292-302.

PubMed Abstract | Publisher Full Text | Free Full Text | F1000 Recommendation

2. National Multiple Sclerosis Society: Disease-modifying therapies for MS. NMSS Brochure. 2019.

Reference Source

3. Hauser SL, Oksenberg JR: The neurobiology of multiple sclerosis: genes, inflammation, and neurodegeneration. Neuron. 2006; 52(1): 61-76. PubMed Abstract | Publisher Full Text

4. Trapp BD, Nave KA: Multiple sclerosis: an immune or neurodegenerative disorder? Annu Rev Neurosci. 2008; 31: 247-69.

PubMed Abstract | Publisher Full Text

5. Stys PK, Zamponi GW, van Minnen J, et al.: Will the real multiple sclerosis please stand up? Nat Rev Neurosci. 2012; 13(7): 507-14. PubMed Abstract | Publisher Full Text

6. Haider L: Inflammation, Iron, Energy Failure, and Oxidative Stress in the Pathogenesis of Multiple Sclerosis. Oxid Med Cell Longev. 2015; 2015: 725370. PubMed Abstract | Publisher Full Text | Free Full Text

7. Can Demirdöğen B: Potential role of calcifying nanoparticles in the etiology of multiple sclerosis. Med Hypotheses. 2019; 128: 25-7. PubMed Abstract | Publisher Full Text

8. Davies S, Nicholson T, Laura M, et al:: Spread of T lymphocyte immune responses to myelin epitopes with duration of multiple sclerosis. J Neuropathol Exp Neurol. 2005; 64(5): 371-7. PubMed Abstract | Publisher Full Tex

9. Maña P, Fordham SA, Staykova MA, et al.: Demyelination caused by the copper chelator cuprizone halts $\mathrm{T}$ cell mediated autoimmune neuroinflammation J Neuroimmunol. 2009; 210(1-2): 13-21. PubMed Abstract | Publisher Full Text

10. Correale J, Gaitán MI, Ysrraelit MC, et al.: Progressive multiple sclerosis: from pathogenic mechanisms to treatment. Brain. 2017; 140(3): 527-546. PubMed Abstract | Publisher Full Text

11. F Abdelhak A, Weber MS, Tumani H: Primary Progressive Multiple Sclerosis: Putting Together the Puzzle. Front Neurol. 2017; 8: 234. PubMed Abstract | Publisher Full Text | Free Full Text | F1000 Recommendation

12. F Leray E, Yaouanq J, Le Page E, et al:: Evidence for a two-stage disability progression in multiple sclerosis. Brain. 2010; 133(Pt 7): 1900-13. PubMed Abstract | Publisher Full Text | Free Full Text | F1000 Recommendation

13. F Luchetti S, Fransen NL, van Eden CG, et al:: Progressive multiple sclerosis patients show substantial lesion activity that correlates with clinical disease severity and sex: a retrospective autopsy cohort analysis. Acta Neuropathol. 2018; 135(4): 511-28.

PubMed Abstract | Publisher Full Text | Free Full Text | F1000 Recommendation

14. F Lassmann H: Pathogenic Mechanisms Associated With Different Clinica Courses of Multiple Sclerosis. Front Immunol. 2019; 9: 3116. PubMed Abstract | Publisher Full Text | Free Full Text | F1000 Recommendation

15. F Elliott $\mathrm{C}$, Belachew S, Wolinsky JS, et al:: Chronic white matter lesion activity predicts clinical progression in primary progressive multiple sclerosis. Brain. 2019; 142(9): 2787-99.

PubMed Abstract | Publisher Full Text | Free Full Text | F1000 Recommendation

16. F Zrzavy T, Hametner S, Wimmer I, et al.: Loss of 'homeostatic' microglia and patterns of their activation in active multiple sclerosis. Brain. 2017; 140(7): 1900-13.

PubMed Abstract | Publisher Full Text | Free Full Text | F1000 Recommendation

17. F University of California, San Francisco MS-EPIC Team, Cree BAC, Hollenbach $\mathrm{JA}$, et al: Silent progression in disease activity-free relapsing multiple sclerosis. Ann Neurol. 2019; 85(5): 653-66.

PubMed Abstract | Publisher Full Text | Free Full Text | F1000 Recommendation

18. Wang Z, Sadovnick AD, Traboulsee AL, et al.: Nuclear Receptor NR1H3 in Familial Multiple Sclerosis. Neuron. 2016; 92(2): 555 PubMed Abstract | Publisher Full Text

19. International Multiple Sclerosis Genetics Consortium: NR1H3 p.Arg415GIn Is Not Associated to Multiple Sclerosis Risk. Neuron. 2016; 92(4): 929. PubMed Abstract | Publisher Full Text

20. Nourbakhsh B, Mowry EM: Multiple Sclerosis Risk Factors and Pathogenesis. Continuum (Minneap Minn). 2019; 25(3): 596-610. PubMed Abstract | Publisher Full Text

21. F Hafler DA, Compston A, Sawcer S, et al:: Risk alleles for multiple sclerosis identified by a genomewide study. N Engl J Med. 2007; 357(9): 851-62. PubMed Abstract | Publisher Full Text | F1000 Recommendation

22. de Jager PL, Jia X, Wang J, et al.: Meta-analysis of genome scans and replication identify CD6, IRF8 and TNFRSF1A as new multiple sclerosis susceptibility loci. Nat Genet. 2009; 41(7): 776-82. PubMed Abstract | Publisher Full Text | Free Full Text

23. Patsopoulos NA, Esposito F, Reischl J, et al.: Genome-wide meta-analysis identifies novel multiple sclerosis susceptibility loci. Ann Neurol. 2011; 70(6): 897-912

PubMed Abstract | Publisher Full Text | Free Full Text

24. F International Multiple Sclerosis Genetics Consortium, Wellcome Trust Case Control Consortium 2, Sawcer S, et al:: Genetic risk and a primary role for cell-mediated immune mechanisms in multiple sclerosis. Nature. 2011; 476(7359): 214-9. PubMed Abstract | Publisher Full Text | Free Full Text | F1000 Recommendation

25. International Multiple Sclerosis Genetics Consortium (IMSGC), Beecham AH, Patsopoulos NA, et al.: Analysis of immune-related loci identifies 48 new susceptibility variants for multiple sclerosis. Nat Genet. 2013; 45(11): 1353-60. PubMed Abstract | Publisher Full Text | Free Full Text

26. Lill CM: Recent advances and future challenges in the genetics of multiple sclerosis. Front Neurol. 2014; 5: 130

PubMed Abstract | Publisher Full Text | Free Full Text

27. Hussman JP, Beecham AH, Schmidt M, et al:: GWAS analysis implicates NF-кBmediated induction of inflammatory T cells in multiple sclerosis. Genes Immun. 2016; 17(5): 305-12.

PubMed Abstract | Publisher Full Text | Free Full Text

28. F International Multiple Sclerosis Genetics Consortium: Multiple sclerosis genomic map implicates peripheral immune cells and microglia in susceptibility. Science. 2019; 365(6460): pii: eaav7188. PubMed Abstract | Publisher Full Text | F1000 Recommendation

29. Moutsianas L, Jostins L, Beecham AH, et al.: Class II HLA interactions modulate genetic risk for multiple sclerosis. Nat Genet. 2015; 47(10): 1107-13. PubMed Abstract | Publisher Full Text | Free Full Text

30. Hensiek AE, Sawcer SJ, Feakes R, et al.: HLA-DR 15 is associated with female sex and younger age at diagnosis in multiple sclerosis. $J$ Neurol Neurosurg Psychiatr. 2002; 72(2): 184-7.

PubMed Abstract | Publisher Full Text | Free Full Text

31. F Hollenbach JA, Oksenberg JR: The immunogenetics of multiple sclerosis: A comprehensive review. J Autoimmun. 2015; 64: 13-25.

PubMed Abstract | Publisher Full Text | Free Full Text | F1000 Recommendation

32. Cree BA: Genetics of primary progressive multiple sclerosis. Handb Clin Neurol. 2014; 122: 211-30.

PubMed Abstract | Publisher Full Text

33. F Okuda DT, Srinivasan R, Oksenberg JR, et al:: Genotype-Phenotype correlations in multiple sclerosis: HLA genes influence disease severity inferred by 1HMR spectroscopy and MRI measures. Brain. 2009; 132(Pt 1): 250-9. PubMed Abstract | Publisher Full Text | Free Full Text | F1000 Recommendation

34. F Lorefice L, Fenu G, Sardu C, et al:: Multiple sclerosis and HLA genotypes: A possible influence on brain atrophy. Mult Scler. 2019; 25(1): 23-30. PubMed Abstract | Publisher Full Text | F1000 Recommendation

35. Strijbis EM, Inkster B, Vounou M, et al:: Glutamate gene polymorphisms predict brain volumes in multiple sclerosis. Mult Scler. 2013; 19(3): 281-8. PubMed Abstract | Publisher Full Text

36. Baranzini SE, Srinivasan $R$, Khankhanian $P$, et al:: Genetic variation influences glutamate concentrations in brains of patients with multiple sclerosis. Brain. 2010; 133(9): 2603-11.

PubMed Abstract | Publisher Full Text | Free Full Text

37. F Siffrin V, Radbruch H, Glumm R, et al.: In Vivo Imaging of Partially Reversible Th17 Cell-Induced Neuronal Dysfunction in the Course of Encephalomyelitis Immunity. 2010; 33(3): 424-36.

PublMed Abstract | Publisher Full Text | F1000 Recommendation

38. Caprariello AV, Rogers JA, Morgan ML, et al.: Biochemically altered myelin triggers autoimmune demyelination. Proc Natl Acad Sci U S A. 2018; 115(21): 5528-33.

PubMed Abstract | Publisher Full Text | Free Full Text

39. Micu I, Plemel JR, Caprariello AV, et al:: Axo-myelinic neurotransmission: A novel mode of cell signalling in the central nervous system. Nat Rev Neurosci. 2018; 19(1): 49-58.

PubMed Abstract | Publisher Full Text

40. Bellamy R: Genetic susceptibility to tuberculosis. Clin Chest Med. 2005; 26(2) 233-46, vi.

PubMed Abstract | Publisher Full Text

41. Ascherio A: Environmental factors in multiple sclerosis. Expert Rev Neurother. 2013; 13(12 Suppl): 3-9.

PubMed Abstract | Publisher Full Text

42. F Alfredsson L, Olsson T: Lifestyle and Environmental Factors in Multiple Sclerosis. Cold Spring Harb Perspect Med. 2019; 9(4): pii: a028944. PubMed Abstract | Publisher Full Text | F1000 Recommendation

43. Haahr S, Höllsberg P: Multiple sclerosis is linked to Epstein-Barr virus infection. Rev Med Virol. 2006; 16(5): 297-310.

PubMed Abstract | Publisher Full Text

44. Munger KL, Levin LI, O'Reilly EJ, et al:: Anti-Epstein-Barr virus antibodies as serological markers of multiple sclerosis: A prospective study among United States military personnel. Mult Scler. 2011; 17(10): 1185-93.

PubMled Abstract | Publisher Full Text | Free Full Text 
45. Handel AE, Williamson AJ, Disanto G, et al.: An updated meta-analysis of risk of multiple sclerosis following infectious mononucleosis. PLoS One. 2010; 5(9): pii: e12496.

PubMed Abstract | Publisher Full Text | Free Full Text

46. $\quad \mathrm{F}$ Levin $\mathrm{LI}$, Munger KL, O'Reilly EJ, et al.: Primary infection with the EpsteinBarr virus and risk of multiple sclerosis. Ann Neurol. 2010; 67(6): 824-30. PubMed Abstract | Publisher Full Text | Free Full Text | F1000 Recommendation

47. F Burnard S, Lechner-Scott J, Scott RJ: EBV and MS: Major cause, minor contribution or red-herring? Mult Scler Relat Disord. 2017; 16: 24-30. PubMed Abstract | Publisher Full Text | F1000 Recommendation

48. Willis SN, Stadelmann C, Rodig SJ, et al:: Epstein-Barr virus infection is not a characteristic feature of multiple sclerosis brain. Brain. 2009; 132(Pt 12): 3318-28.

PubMed Abstract | Publisher Full Text | Free Full Text

49. Magliozzi R, Serafini B, Rosicarelli B, et al.: B-Cell Enrichment and Epstein-Barr Virus Infection in Inflammatory Cortical Lesions in Secondary Progressive Multiple Sclerosis. J Neuropathol Exp Neurol. 2013; 72(1): 29-41. PubMed Abstract | Publisher Full Text

50. F Guan $Y$, Jakimovski D, Ramanathan M, et al.: The role of Epstein-Barr virus in multiple sclerosis: From molecular pathophysiology to in vivo imaging. Neural Regen Res. 2019; 14(3): 373-386.

PubMed Abstract | Publisher Full Text | Free Full Text | F1000 Recommendation

51. F Pender MP, Csurhes PA, Smith C, et al.: Epstein-Barr virus-specific $T$ cell therapy for progressive multiple sclerosis. JCI Insight. 2018; 3(22): pii: 124714 PubMed Abstract | Publisher Full Text | Free Full Text | F1000 Recommendation

52. F Lisak RP, Nedelkoska L, Benjamins JA, et al.: B cells from patients with multiple sclerosis induce cell death via apoptosis in neurons in vitro. J Neuroimmunol. 2017; 309: 88-99.

PubMed Abstract | Publisher Full Text | F1000 Recommendation

53. Bø L, Vedeler CA, Nyland $\mathrm{H}$, et al:: Intracortical multiple sclerosis lesions are not associated with increased lymphocyte infiltration. Mult Scler. 2003; 9(4) 323-31.

PubMed Abstract | Publisher Full Text

54. Popescu BF, Lucchinetti CF: Meningeal and cortical grey matter pathology in multiple sclerosis. BMC Neurol. 2012; 12: 11. PubMed Abstract | Publisher Full Text | Free Full Text

55. F McKeithan LJ, Lyttle BD, Box BA, et al:: $7 \mathrm{~T}$ quantitative magnetization transfer (qMT) of cortical gray matter in multiple sclerosis correlates with cognitive impairment. Neuroimage. 2019; 203: 116190. PubMed Abstract | Publisher Full Text | F1000 Recommendation

56. F Ighani M, Jonas S, Izbudak I, et al:: No association between cortical lesions and leptomeningeal enhancement on 7-Tesla MRI in multiple sclerosis. Mult Scler. 2019; 135245851987603

PubMed Abstract | Publisher Full Text | F1000 Recommendation

57. F Eijlers AJC, Dekker I, Steenwijk MD, et al.: Cortical atrophy accelerates as cognitive decline worsens in multiple sclerosis. Neurology. 2019; 93(14): e1348-e1359.

PubMed Abstract | Publisher Full Text | F1000 Recommendation

58. Peterson JW, Bö L, Mörk S, et al:: Transected neurites, apoptotic neurons, and reduced inflammation in cortical multiple sclerosis lesions. Ann Neurol. 2001; 50(3): 389-400.

PubMed Abstract | Publisher Full Text

59. Geurts JJG, Barkhof F: Grey matter pathology in multiple sclerosis. Lancet Neurol. 2008; 7(9): 841-51.

PubMed Abstract | Publisher Full Text

60. Vercellino M, Masera S, Lorenzatti M, et al: Demyelination, inflammation, and neurodegeneration in multiple sclerosis deep gray matter. $J$ Neuropathol Exp Neurol. 2009; 68(5): 489-502.

PubMed Abstract | Publisher Full Text

61. Klaver R, De Vries HE, Schenk GJ, et al.: Grey matter damage in multiple sclerosis: a pathology perspective Prion 2013; 7(1): 66-75. PubMed Abstract | Publisher Full Text | Free Full Text

62. F Eshaghi A, Marinescu RV, Young AL, et al:: Progression of regional grey matter atrophy in multiple sclerosis. Brain. 2018; 141(6): 1665-77. PubMed Abstract | Publisher Full Text | Free Full Text | F1000 Recommendation

63. $\mathrm{F}$ Bevan RJ, Evans R, Griffiths L, et al.: Meningeal inflammation and cortical demyelination in acute multiple sclerosis. Ann Neurol. 2018; 84(6): 829-42. PubMed Abstract | Publisher Full Text | F1000 Recommendation

64. Cooper GS, Stroehla BC: The epidemiology of autoimmune diseases. Autoimmun Rev. 2003; 2(3): 119-25.

PubMed Abstract | Publisher Full Text

65. Wong WT: Microglial aging in the healthy CNS: phenotypes, drivers, and rejuvenation. Front Cell Neurosci. 2013; 7: 22

PubMed Abstract | Publisher Full Text | Free Full Text

66. Kutzelnigg $\mathrm{A}$, Lassmann $\mathrm{H}$ : Pathology of multiple sclerosis and related inflammatory demyelinating diseases. Handb Clin Neurol. 2014; 122: 15-58. PubMed Abstract | Publisher Full Text

67. De Groot CJ, Woodroofe MN: The role of chemokines and chemokine receptors in CNS inflammation. Prog Brain Res. 2001; 132: 533-44. PubMed Abstract | Publisher Full Text

68. F Airas L, Nylund M, Rissanen E: Evaluation of Microglial Activation in Multiple Sclerosis Patients Using Positron Emission Tomography. Front Neurol. 2018; 9: 181.

PubMed Abstract | Publisher Full Text | Free Full Text | F1000 Recommendation

69. Debruyne JC, Versijpt J, van Laere KJ, et al:: PET visualization of microglia in multiple sclerosis patients using [ ${ }^{11}$ C]PK11195. Eur J Neurol. 2003; 10(3): 257-64. PubMed Abstract | Publisher Full Text

70. F Politis M, Giannetti P, Su P, et al:: Increased PK11195 PET binding in the cortex of patients with MS correlates with disability. Neurology. 2012; 79(6): 523-30. PubMed Abstract | Publisher Full Text | Free Full Text | F1000 Recommendation

71. Herranz E, Giannì C, Louapre C, et al:: Neuroinflammatory component of gray matter pathology in multiple sclerosis. Ann Neurol. 2016; 80(5): 776-90. PubMed Abstract | Publisher Full Text | Free Full Text

72. Airas L, Rissanen E, Rinne JO: Imaging neuroinflammation in multiple sclerosis using TSPO-PET. Clin Transl Imaging. 2015; 3: 461-73. PubMed Abstract | Publisher Full Text | Free Full Tex

73. F Singhal T, O'Connor K, Dubey S, et al:: Gray matter microglial activation in relapsing vs progressive MS: A [F-18]PBR06-PET study. Neurol Neuroimmunol Neuroinflamm. 2019; 6(5): e587.

PubMed Abstract | Publisher Full Text | Free Full Text | F1000 Recommendation

74. Trapp BD, Stys PK: Virtual hypoxia and chronic necrosis of demyelinated axons in multiple sclerosis. Lancet Neurol. 2009; 8(3): 280-91.

PubMed Abstract | Publisher Full Text

75. Lassmann $\mathrm{H}$ : Multiple sclerosis: lessons from molecular neuropathology. Exp Neurol. 2014; 262 Pt A: 2-7.

PubMed Abstract | Publisher Full Text

76. Bolaños JP, Almeida A, Stewart V, et al:: Nitric oxide-mediated mitochondrial damage in the brain: mechanisms and implications for neurodegenerative diseases. J Neurochem. 1997; 68(6): 2227-40.

PubMed Abstract | Publisher Full Text

77. Lutz NW, Viola A, Malikova I, et al.: Inflammatory multiple-sclerosis plaques generate characteristic metabolic profiles in cerebrospinal fluid. PLOS One. 2007; 2(7): e595.

PubMed Abstract | Publisher Full Text | Free Full Text

78. Albanese M, Zagaglia S, Landi D, et al.: Cerebrospinal fluid lactate is associated with multiple sclerosis disease progression. J Neuroinflammation. 2016; 13: 36 PubMed Abstract | Publisher Full Text | Free Full Text

79. Regenold WT, Phatak P, Makley MJ, et al:: Cerebrospinal fluid evidence of increased extra-mitochondrial glucose metabolism implicates mitochondrial dysfunction in multiple sclerosis disease progression. J Neurol Sci. 2008; 275(1-2): 106-12.

PubMed Abstract | Publisher Full Text | Free Full Text

80. F Wentling M, Lopez-Gomez C, Park HJ, et al:: A metabolic perspective on CSF-mediated neurodegeneration in multiple sclerosis. Brain. 2019; 142(9): $2756-74$.

PubMed Abstract | Publisher Full Text | F1000 Recommendation

81. Dutta R, McDonough J, Yin X, et al:: Mitochondrial dysfunction as a cause of axonal degeneration in multiple sclerosis patients. Ann Neurol. 2006; 59(3): 478-89.

PubMed Abstract | Publisher Full Text

82. F Campbell GR, Ziabreva I, Reeve AK, et al:: Mitochondrial DNA deletions and neurodegeneration in multiple sclerosis. Ann Neurol. 2011; 69(3): 481-92. PubMed Abstract | Publisher Full Text | Free Full Text | F1000 Recommendation

83. Campbell GR, Mahad DJ: Clonal expansion of mitochondrial DNA deletions and the progression of multiple sclerosis. CNS Neurol Disord Drug Targets. 2012; 11(5): 589-97.

PubMed Abstract | Publisher Full Tex

84. F Campbell G, Mahad DJ: Mitochondrial dysfunction and axon degeneration in progressive multiple sclerosis. FEBS Lett. 2018; 592(7): 1113-21. PubMed Abstract | Publisher Full Text | F1000 Recommendation

85. Campbell GR, Reeve AK, Ziabreva I, et al.: No excess of mitochondrial DNA deletions within muscle in progressive multiple sclerosis. Mult Scler. 2013; 19(14): 1858-66.

PubMed Abstract | Publisher Full Text | Free Full Text 


\section{Open Peer Review}

\section{Current Peer Review Status:}

\section{Editorial Note on the Review Process}

Faculty Reviews are review articles written by the prestigious Members of Faculty Opinions. The articles are commissioned and peer reviewed before publication to ensure that the final, published version is comprehensive and accessible. The reviewers who approved the final version are listed with their names and affiliations.

\section{The reviewers who approved this article are:}

\section{Version 1}

\section{Frauke Zipp}

Department of Neurology, University Medical Center of the Johannes Gutenberg University Mainz, Mainz, Germany

Competing Interests: No competing interests were disclosed.

\section{Ranjan Dutta}

Department of Neurosciences, Lerner Research Institute, Cleveland Clinic, Cleveland, USA

Competing Interests: No competing interests were disclosed.

The benefits of publishing with F1000Research:

- Your article is published within days, with no editorial bias

- You can publish traditional articles, null/negative results, case reports, data notes and more

- The peer review process is transparent and collaborative

- Your article is indexed in PubMed after passing peer review

- Dedicated customer support at every stage

For pre-submission enquiries, contact research@f1000.com 